И. А. Ашмаров

Воронежский государственный институт искуссть, г. Воронеж, Российская Федерация

\title{
К ВОПРОСУ О ПЕРИОДИЗАЦИИ ПОСЛЕВОЕННОЙ ЭКОНОМИЧЕСКОЙ ИСТОРИИ ЯПОНИИ
}

Аннотация. В данной статье уделяется особое внимание основным вехам развития послевоенной экономической истории Японии. Периодизация послевоенной экономической истории Японии позволяет представить ход восстановления и развития японской экономики и основные рубежные этапы этого восстановления и развития. Уделено первостепенное внимание сложившейся социально-экономической ситуации на каждом этапе развития японской экономики в послевоенный период 1940-х - 2010-х гг.

Целью исследования является теоретический анализ и эмпирическое исследование количественных и качественных характеристик послевоенного экономического развития Японии в послевоенный период.

Предметом исследования является эволюция японской экономики. Мы разделяем послевоенную экономическую историю Японии на несколько основных этапов, а именно: 1. 1945-1955 гг.; 2. Вторая половина 1950-х - 1960-е гг.; 3. 1970-е гг.; 4. 1980-е гг. 2010-е гг. Хронология этих этапов весьма красноречиво показывает нам главные вехи экономической эволюции «страны восходящего солнца».

Теоретико-методологической основой исследования были статистика и работы отечественных и зарубежных историков и ученых, таких как А. И. Динкевича, О. Г. Барышниковой, В. И. Дунаева, В. Рамзеса, Н. Енэмура, Х. Цукамото и других авторов.

Ключевые слова. Экономика Японии в послевоенный период времени, японское экономическое «чудо». 


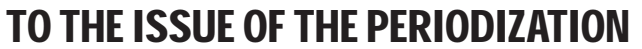

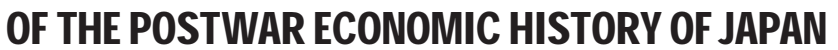

Abstract. This article focuses on the main milestones of Japan's post-war economic history. Periodization of Japan's post-war economic history allows us to present the course of the restoration and development of the Japanese economy and the main milestones in its recovery and development. Priority was given to the current social and economic situation at each stage of the development of the Japanese economy in the post-war period of the 1940s - 2010s.

The aim of the study is a theoretical analysis and an empirical study of the quantitative and qualitative characteristics of Japan's post-war economic development in the post-war period.

The subject of the study is the evolution of the Japanese economy. We divide the post-war economic history of Japan in several main stages, namely: 1. 1945-1955; 2. the second half of the 1950s - 1960s; 3. The 1970s; 4 . The 1980s - 2010s. The chronology of these stages eloquently shows us the main milestones of the economic evolution of the country of the rising sun.

The theoretical and methodological basis of the study was statistical data and the work of domestic and foreign historians and scientists, such as A. I. Dinkevich, O. G. Baryshnikova, V. I. Dunaev, V. Ramses, N. Enamura, H. Tsukamoto and other authors.

Keywords. The economy of Japan in the post-war period, the Japanese economic «miracle».

Периодизация послевоенной экономической истории Японии позволяет нам более чётко и фигурально представить ход восстановления и развития японской экономики и основные рубежные этапы этого восстановления и развития. Разрушительная по своему характеру вторая мировая война нанесла внушительный 
урон множеству стран мира и их экономикам соответственно. Её последствия невероятно ослабили всю мировую экономику и на долгие годы затормозили ее развитие, её пришлось возрождать буквально из руин.

С особенным, неподдельным интересом хочется рассмотреть феномен послевоенного экономического развития Японии, получившее у историков вполне справедливое название японского экономического «чуда». Государство, не обладающее богатыми природными ресурсами, с обнищавшим населением, чрезвычайно низкими послевоенными условиями для существования (таких как жилье, продовольствие и работа), поднялось с колени и за несколько десятилетий переросло в экономически сильную державу.

Попытаемся проанализировать периоды становления японской экономики после окончания второй мировой войны. Экономическое развитие Японии в послевоенное время можно разделить на несколько основных этапов.

В качестве первого этапа условно можно обозначить время с момента окончания войны в 1945 году и до середины 1950-х гг. В принципе Япония не была единственным в мире государством, оказавшимся по окончании войны в состоянии экономической разрухи. Несмотря на то, что военные действия не нанесли существенного ущерба производственно-технической базе страны (даже учитывая атомные бомбардировки американцами японских городов Хиросимы и Нагасаки), экономическое состояние государства было кризисным. Почти полностью прекратился импорт сырья и продовольствия, была закрыта основная часть предприятий. К началу 1946 г. уровень промышленной продукции достигал лишь 14 \% от довоенного уровня [1].

Следует вспомнить, что Япония, претерпевшая поражение в войне, находилась в оккупации американскими властями, поэтому экономическое развитие 2018. T. 19, № 1. C. 121-132 
страны в ближайшие послевоенные годы проходило согласно американским интересам и стандартам и регламентировалось условиями Потсдамской декларации, принятой в отношении Японии еще в июле 1945 года [2].

Изначально США не ставили себе цель возродить японскую экономику после войны, но во избежание усиления конфликтов социально-политических, связанных отчасти с саботажем местными властями оккупационных властей, были вынуждены оказать поддержку японской экономике.

В первую очередь была проведена земельная реформа, осуществленная в течение 1946 - 1949 гг. В результате собственность на обрабатываемую землю была практически совсем ликвидирована, ограничившись лишь несколькими гектарами. Натуральная плата уступила место денежной. Эта реформа стала своего рода решающей, поскольку способствовала повышению товарности сельского хозяйства и дала толчок к возрождению внутреннего рынка [3].

Постепенно претерпела серьёзные изменения и японская промышленность. Исторически экономика Японии характеризовалась достаточно значительной степенью монополизации. Оккупационные власти принесли решение распустить исторически знаменитые монополистические холдинги, и это было обусловлено не только экономическими, но и политическими мотивами. Также были проведены меры по изменению и улучшению ценовой и финансовой политики, что во многом было связано с нарастанием инфляции и обесцениванием японской валюты. В 1949 г. американские оккупанты взялись за осуществление так называемого плана по экономической стабилизации Японии, разработанного финансистом из США.

Важную роль в возрождении японской экономики сыграла корейская война, разгоревшаяся в июне 1950 г., так как Япония на это время превратилась в сво- 
еобразный тыл для американской армии. К 1951 году японскому государству удалось не только достичь, но и превысить довоенные экономические показатели. Период оккупации Японии положительно повлиял на экономическое развитие страны и дал толчок в правильное русло.

Следующим этапом послевоенного становления японской экономики можно обозначить середину 1950-х - конец 1960-х гг. Именно в это время сформировался современный образ Японии как высокоразвитого промышленного государства. Темпы роста японской экономики приняли небывалый размах, появилось новое историческое понятие - так называемое «японское экономическое чудо». В первой половине 1950-х японские власти сместили главный акцент на совершенствование внешнеэкономических связей.

В 1952 г. Япония стала членом Международного валютного фонда (МВФ). Экспорт продукции всячески поощрялся, в том числе практиковалось субсидирование. Импорт распространялся главным образом на покупку продукции (сырья, оборудования), необходимой для модернизации промышленности, а приток в страну иностранного капитала ограничивался [4].

В связи с промышленным усовершенствованием и перевооружением, в структуре японской индустрии происходят определенные изменения. Во второй половине 1950-х гг. трудоемкое производство, требующее большое количество трудовых ресурсов, рабочих рук, уступает место капиталоемкому производству, рассчитанному на внушительные капиталовложения и высокий уровень профессионализма рабочих. В связи с этим обороты легкой промышленности естественно сократились, но начали развиваться новые отрасли, такие как автомобилестроение, электротехника, синтетическое производство [6].

С середины 1960-х гг. последовал следующий этап модернизации, связанный с переходом к наукоемко2018. T. 19, № 1. C. 121-132 
му производству. Япония активно использовала научно-технические достижения других стран, широко закупала лицензии и патенты на изобретения. Это был этап знаменитого сегодня на весь мир «японского экономического чуда» - исторического феномена рекордного роста японской экономики, начавшегося с середины 1950-х и продолжавшегося до начала 1970-х годов (в первую очередь в связи с нефтяным кризисом 1973 г.). Рост экономики в это время был около $10 \%$ ежегодно, и это были самые высокие темпы роста среди всех развитых стран мира.

Во многом экономическое преуспевание Японии в эти годы связано с исключительным качеством и необыкновенной инициативностью рабочих всех уровней (на это, безусловно, повлияла проведенная еще в 1947 г. образовательная реформа). В общей сложности за этот период уровень промышленности по сравнению с довоенным вырос более чем на $20 \%$.

Новый этап в развитии экономической истории Японии приходится на 1970-е гг. Переход к этому этапу был вполне логичным, естественным и неизбежным, так как используемый вектор экономического развития исчерпал себя. Переход к новому типу должен был осуществиться постепенно, однако «нефтяной шок», который пришелся на первую половину 1970-х гг., явился причиной экономического кризиса в 1974 - 1975 гг. и стал толчком к незамедлительному реформированию модели дальнейшего экономического развития. Первой пошатнулась система ресурсообеспечения, формировавшаяся в течение всего послевоенного периода. Кризис затронул черно-металлургическую промышленность, т. е. автопроизводство, судостроение, что привело к упадку металлургической промышленности в целом.

Но не один только внутренний кризис поколебал экономику Японии. Отрицательную роль также сыграли и мировые кризисы, разразившиеся в 1970-х - 
1980-х гг., что, в свою очередь, выявило сильную зависимость державы от внешних экономических рынков. Вдобавок, другие страны тоже не стояли на месте в своем развитии и в результате такие государства, как Китай, Корея и др. стали более привлекательными для международного рынка, так как им удалось удешевить производство металлопродукции. Обострились и экономические отношения с Соединенными Штатами, которые многие годы являлись для Японии основой международного рынка.

Всё это заставило Японию скорректировать свою политику в отношении экономики. Было решено заменить ценовую конкуренцию на неценовую. Это предполагало захват иностранных рынков не за счет низкой цены, а за счет уникального качества продукции высокого уровня обслуживания, одобрения кредита и надежности поставок. Выдающуюся роль в развитии экономической конкурентоспособности сыграла запущенная в 1980-е гг. автоматизация и компьютеризация производственного процесса, обогнавшая в темпах развития США и европейские державы. Хотя в целом показатели роста промышленного производства были относительно слабыми по сравнению с предыдущим периодом, но само качество развития, его новое направление позволяет дать неплохую оценку этому периоду.

Следующий этап развития японской экономики охватывает время, начиная с 1980-х гг. и до наших дней. С середины 1980-х гг. мировая экономика постепенно выходит из кризиса, однако важно отметить переориентацию приоритетов Японии с внешнего рынка на внутренний.

Прекращение «японского чуда», по оценкам экспертов, следует относить к 1985 году, когда Япония подписала знаменитые «Плаза-соглашения» (по имени отеля, в котором они были подписаны), в результате которых иена ревальвировалась, то есть выросла 2018. T. 19, № 1. C. 121-132 
примерно в 1,5 раза, а темп экономического роста в Японии, наоборот, упал с 8 \% до 2 \% [5].

Тем не менее, Япония как ведущая мировая держава не теряет своих лидерских позиций в мировой экономике; валовой национальный продукт страны намного превосходит ВНП европейских стран и Соединенных Штатов Америки.

Современная Япония совершает активный переход к экологичному производству согласно экологическим стандартам, принятым еще на рубеже 1960-х 1970-х гг. Сюда относится не только экологически чистые технологии производства, а также возможности переработки отходов. Так, например, сжигание мусора позволяло вырабатывать энергию теплоты, которая, в свою очередь, позволяла производить огромный объем электроэнергии, что принесло Японии миллиардную прибыль.

На рубеже 1980-х - 1990-х гг. Япония по праву становится экономической сверхдержавой. Основными факторами конкурентоспособности японской продукции на иностранных рынках можно назвать, во-первых, исключительную систему за контролем качества продукции, во-вторых, невероятный рост производительности труда и, наконец, направление большей части накоплений в производство. Япония не только сумела достичь выдающегося технического уровня в большинстве отраслей производства, но и создала мощные заделы на рынке технологий будущего. Несмотря на политику демилитаризации, проводившуюся американскими оккупантами в послевоенные годы, в настоящее время в Японии существует относительно развитая военная промышленность.

Японцы все так же трепетно относятся к образованию, так как наука является определяющим фактором в структуре развития экономики. Если раньше государство приобретало патенты на достижения в других странах, то в настоящее время в Японии основаны 
собственные научные центры, в которых ведутся разработки новейших технологий в различных областях (например, атомная энергетика, физика плазмы, космические роботы и др.).

В заключение хочется еще раз отметить, насколько быстро и мужественно Япония сумела оправиться от поражения во второй мировой войне и вывести свою экономику на решительно новый уровень, обогнав множество не менее развитых капиталистических стран при отсутствии богатых природных ресурсов. Сегодня эта страна, Япония, по праву заслуживает статус экономической сверхдержавы, успешно конкурирующей с первой экономикой мира, экономикой США.

Таблица

Хронология и краткая характеристика этапов развития послевоенной экономики Японии

\begin{tabular}{|l|l|l|}
\hline $\begin{array}{l}\text { № } \\
\text { пп }\end{array}$ & $\begin{array}{l}\text { Хронология } \\
\text { этапов }\end{array}$ & Краткая характеристика \\
\hline 1. & $1945-1955$ гг. & $\begin{array}{l}\text { Послевоенное восстановление эко- } \\
\text { номики, проведение экономических } \\
\text { реформ }\end{array}$ \\
\hline 2. & $\begin{array}{l}\text { Вторая половина } \\
\text { 1950-х - 1960-е гг. }\end{array}$ & $\begin{array}{l}\text { Этап модернизации экономики, свя- } \\
\text { занный с переходом к наукоемкому } \\
\text { производству, или т. н. «японское эко- } \\
\text { номическое чудо» }\end{array}$ \\
\hline 3. & $\begin{array}{l}\text { Продолжение роста экономики Япо- } \\
\text { нии, сдерживаемое начавшимся в 1973 } \\
\text { году мировым кризисом. }\end{array}$ \\
\hline 4. & $\begin{array}{l}\text { 1980-е гг. - } \\
\text { 2010-е гг. }\end{array}$ & $\begin{array}{l}\text { Ревальвация японской националь- } \\
\text { ной валюты (иены), падение темпов } \\
\text { экономического развития Японии с } \\
8 \text { \% до 2 \%. Более сорока лет Япония } \\
\text { считалась второй экономикой мира, а } \\
\text { именно: с 1968 года, уступив место Ки- } \\
\text { тайской Народной Республике в 2010 } \\
\text { году [7]. }\end{array}$ \\
\hline
\end{tabular}

Таким образом, чрезвычайно быстрые темпы послевоенного восстановления и развития экономики 2018. T. 19, № 1. C. 121-132 
Японии позволили стране полностью восстановиться после своего военно-политического поражения во второй мировой войне, а также выйти по своей номинальной экономической мощи на второе место, последовательно обойдя все европейские страны, в том числе Францию, Италию, Канаду, Великобританию, ФРГ, уступая только Соединённым Штатам Америки. К главным выводам, которые нам следует перенять, это то, что интенсивное освоение новых научных технологий и низкие налоги выступают эффективными акселераторами социально-экономического развития и роста. Так было в послевоенной Японии. Точно так же может быть и в современной России, если только мы сможем применить полученные другими нациями рецепты оздоровления экономики в реальной хозяйственной и политической практике.

\section{Өписок использованной литературы}

1. Динкевич А. И. Промышленность Японии в послевоенный период (1945-1956 гг.) / А. И. Динкевич, О. Г. Барышникова. - М. : Знание, 1958. - 107 с.

2. Дунаев В. И. Японцы «на рубежах» / В. И. Дунаев. М. : Молодая гвардия, 1983. - 160 с.

3. Енэмура Н. Опыт послевоенной Японии в реформировании экономики / Н. Енэмура, Х. Цукамото / / Вопросы экономики. - 1992. - № 11. - С. 82-92.

4. Япония: снова на марше? / отв. ред. В. Рамзес. - М. : Вост. лит., 2001. - 296 с.

5. История Японии / под ред. А. Е. Жукова. - М. : Институт Востоковедения РАН, 1998. - Т. 2 : 1868-1998. - 703 с.

6. Примачук И. П. Экономика Японии после второй мировой войны. Реформы второй половины 40-х - первой половины 50-х гг. XX в. [Электронный ресурс] // Голубович В. И. Экономическая история зарубежных стран. 1997. - Режим доступа: http:/ / uchebnik-online.com/130/157.html.

7. Ellington L. Learning from the Japanese Economy [Electronic resource] / L. Ellington // Japan Digest. - 2004. September // Stanford. SPICE. Mode of access: https://spice.fsi. stanford.edu/docs/learning_from_the_japanese_economy. 
1. Dinkevich A. I., Baryshnikova O. G. Promyshlennost' Yaponii $v$ poslevoennyi period (1945-1956 gg.) [Japanese industry in the postwar period (1945-1956)]. Moscow, Znanie Publ., 1958. 107 p.

2. Dunaev V. I. Yapontsy «na rubezhakh» [Japanese people at the leading edges]. Moscow, Molodaya gvardiya Publ., 1983. 160 p.

3. Enemura N., Tsukamoto Kh. Postwar Japan's experience in economic reform. Voprosy ekonomiki = Economic issues, 1992, no 11, pp. 82-92.

4. Ramzes V. (ed.). Yaponiya: snova na marshe? [Japan: on the march once again?]. Moscow, Vostochnaya literatura Publ., 2001. $296 \mathrm{p}$.

5. Zhukov A. E. (ed.). Istoriya Yaponii [History of Japan]. Moscow, Institut Vostokovedeniya RAN Publ., 1998, vol. 2. 703 p.

6. Primachuk I. P. The Japanese economy after the World War II. Reforms of the second half of the 1940s - the first half of the 1950s. Available at: http://uchebnik-online.com/130/157.html. (In Russian).

7. Ellington L. Learning from the Japanese Economy. Japan Digest, 2004, September. Available at: https:/ / spice.fsi.stanford.edu/ docs/learning_from_the_japanese_economy.

\section{Информация об авторе}

Ашмаров Игорь Анатольевич - кандидат экономических наук, доцент, кафедра гуманитарных и социально-экономических дисциплин, Воронежский государственный институт искусств (ВГИИ), 394053, Россия, г. Воронеж, ул. Генерала Лизюкова, 42, e-mail: dobrinka75@mail.ru.

C

Igor A. Ashmarov - PhD in Economics, Associate Professor of the Chair of Humanitarian and Socio-Economic Disciplines, Voronezh State Institute of Arts, 42, General Lizyukov st., Voronezh, 394053, Russian Federation, e-mail: dobrinka75@ mail.ru.

\section{Для цитирования}

Ашмаров И. А. К вопросу о периодизации послевоенной экономической истории Японии / И. А. Ашмаров // Историко-экономические исследования. - 2018. - Т. 19, № 1. - C. 121-132. - DOI: 10.17150/2308-2588.2018.19(1).121132. 
Ashmarov I. A. To the Issue of the Periodization of the Postwar Economic History of Japan. Istoriko-ekonomicheskie issledovaniya = Journal of Economic History \& History of Economics, 2018, vol. 19, no. 1, pp. 121-132. DOI: 10.17150/23082588.2018.19(1).121-132. (In Russian). 